\title{
ANALYSIS OF CROP PATTERN PLANT AND IRRIGATION WATER NEEDS IN PAUH TINGGI IRIGATION NETWORK PLANNING, PAUH TINGGI VILLAGE, KERINCI DISTRICT, JAMBI
}

\author{
Acep, HIDAYAT \\ Faculty of Engineering, University Mercu Buana Jakarta, Indonesia \\ acep_hidayat@mercubuana.ac.id \\ Muhammad Al Reza, HIDAYATULLAH \\ Faculty of Engineering, University Mercu Buana Jakarta, Indonesia \\ muhalreza7@gmail.com
}

\begin{abstract}
Pauh Tinggi irrigation network planning which has an area of irrigation land of 473 ha. This irrigation plan draws water from the Pauh Tinggi Dam located in the Batanghari Hulu river, Kerinci Regency, Jambi. Population growth which is directly proportional to the increasing necessities of life, one of which is in the food sector, has made the government take the initiative to meet the needs and welfare of the community by opening land into productive areas of rice fields and fields, and making irrigation plans. In making irrigation planning, hydrological and rainfall calculations are needed to be able to make the right cropping system for farmers in Pauh Tinggi Village, Kerinci Regency, Jambi. A calculation of 17 alternative cropping patterns with different types of plant variants and different plans for the initial planting period were carried out by comparing with the mainstay debit factor (Q80). It was found that the cropping pattern is very possible always using the RICE-RICE-CROP cropping pattern. The most efficient and optimal planting pattern is the alternative planting pattern 14 in the form of RICE -RICE-CORN with Netto Field Water Requirements in tertiary plots (NFR tertiary) ranging from $0-1.30 \mathrm{ltr} / \mathrm{sec} /$ ha with a maximum of $1.30 \mathrm{ltr} / \mathrm{sec} / \mathrm{ha}$ in January I, while irrigation water needs in the intake (DR intake) range $0-1.60 \mathrm{ltr} \mathrm{sec} / \mathrm{ha}$ with a maximum of $1.60 \mathrm{ltr} / \mathrm{sec} / \mathrm{ha}$ in January I.
\end{abstract}

Keywords : Cropping pattern, Pauh Tinggi irrigation network, Mainstay debit, Irrigation Water Needs

\section{INTRODUCTION}

Irrigation is a human effort in irrigating plants that need water, useful for growing plants to get the benefits. According to The Republic of Indonesia UU No. 7 of 1996 (UU RI No.7 1996) concerning Food, states that food is a basic human need whose fulfillment is the basic right of every Indonesian people in realizing quality human resources to carry out national development.

Based on this, the Kerinci Regency Government cleared unused land into productive areas in several villages within its territory. Population growth which is directly proportional to the increasing need for living one of them in the food sector,makes the government take the initiative in meeting the needs and welfare of the community by opening land into productive areas of rice fields and fields, and making irrigation plans.

One area in Kerinci Regency that needs hydraulic analysis is the Planning of Pauh Tinggi irrigation network which has an irrigation area of 473 ha. This irrigation plan draws water from the Pauh Tinggi Dam located in the Batanghari Hulu river, Kerinci Regency, Jambi, taking into account the right and best planting patterns for the people of Pauh Tinggi Village, Kerinci Regency, Jambi. 


\section{Definition of Irrigation.}

Irrigation is the business of supplying, regulating, and discharging irrigation water to support agriculture of which typically includes surface irrigation, swamp irrigation, underground water irrigation, pump irrigation, and pond irrigation (Permen PUPERA, 2015)

Based on Ministerial Decree No. 32 of 2007, Irrigation is an effort to supply, regulate and dispose of irrigation water to support agriculture which includes surface, swamp, underground water, pumps, and ponds.

According to (Gandakoesoema, 1986) in his book explained that irrigation is away and effort to bring in water by making buildings and channels. Then drain and distribute water in the channel to the fields and fields in an orderly manner and dispose of the water that is no longer used into the drain.

In the opinion of the expert (Sidharta, 1997) in his book that the purpose of irrigation in an area is to supply and regulate water to support agriculture, from upstream water sources to areas that need water and are distributed technically and systematically

\section{Elements and levels of irrigation networks}

Based on the way the water flow measurements are arranged and the facilities are complete, the irrigation network can be divided into three levels namely:

1. Simple

2. Technical

3. Technical.

(KP 01, 2013)

\section{Hydrological Analysis}

The hydrological analysis is one part of the whole series in water planning. Hydrological data is a collection of information or facts about hydrological phenomena. Hydrological data is an important information material in carrying out an inventory of potential water sources, utilization and management of appropriate water sources.

\section{Regional Rainfall}

There are several types of methods that can be used to calculate rainfall in a watershed from the local rainfall record at the rainfall gauge station:

\section{Average Calculation Method}

The arithmetic means the method is the simplest. This method is usually used for flat areas, with a considerable amount of rainfall and with the assumption that rainfall in the area is uniform (uniform distribution).

Formula:

$$
\begin{aligned}
& \operatorname{Rav}=(\mathrm{R} 1+\mathrm{R} 2+\mathrm{R} 3+\ldots \mathrm{Rn}) / \mathrm{n} \ldots \ldots \ldots \ldots \ldots . . . \\
& \text { Information: } \\
& \mathrm{Rav} \quad=\text { average rainfall }(\mathrm{mm}) \\
& \mathrm{n} \quad=\text { number of rain measurement stations } \\
& \mathrm{R} 1 \ldots \mathrm{Rn}=\text { the amount of rainfall at each station }(\mathrm{mm}) \\
& \text { (Kurniawan, 2018) }
\end{aligned}
$$

\section{Search of Missing Data}

Linsley, Kohler and Paulhus (1958) suggest a method called the "Normal Ratio Method" as follows:

$D x=1 / n \times \Sigma[(d / A n 1) x A n x] d x$

(Anonym, 2017) 


\section{Effective Rainfall}

Effective rainfall is the amount of rainfall that falls in a certain period during the growth of plants that can effectively meet the needs of plants (can be used by plants) (Sucipto, 2008: 3).

Effective rainfall uses the Basic Years method which is calculated by analyzing the formula as follows:

Re palawija $=50 \%$. R80

Re rice $=70 \%$. R80

Re Sugar cane $=60 \%$. R80

(Anton , 2014)

\section{Mainstay Rainfall}

Mainstay rainfall is rainfall that can be relied upon throughout the year. To get this data, the monthly rainfall is totaled, then sorted from the smallest to the largest data. Mainstay discharge is a reliable debit for a certain level of reliability or reliability. For irrigation purposes, reliable discharge is used with a reliability of $80 \%$ as stipulated in the Irrigation Planning Criteria (Kementerian PUPR Ditjen Sumber Daya Air, 2017).

The mainstay rainfall calculation is done by the formula:

$\mathrm{R} 80=\mathrm{n} / 5+1$

\section{Planting Patterns}

Planting pattern is the most important way in planting system planning. The purpose of holding a planting system is to set the time, place, type and area of plants in the irrigation area. The purpose of the planting system is to utilize the irrigation water supply as effectively and efficiently as possible so that the plants can grow well.

\section{Plant Coefficients}

Plant coefficients are given to link evapotranspiration (ETo) with reference plant evapotranspiration (ETtanam) and are used in the Penman formula. The coefficient used must be based on continuous experience (KP 01, 2013)

Table 1. Price of paddy crop coefficient

\begin{tabular}{|c|c|c|c|c|}
\hline \multirow[b]{2}{*}{ Bulan } & \multicolumn{2}{|c|}{ Nedeco/ Prosida } & \multicolumn{2}{|c|}{ FAO } \\
\hline & $\begin{array}{c}\text { Varietas }^{2} \\
\text { Biasa }\end{array}$ & $\begin{array}{c}\text { Varietas }^{3} \\
\text { Ungqul }\end{array}$ & $\begin{array}{c}\text { Varietas } \\
\text { biasa }\end{array}$ & $\begin{array}{c}\text { Variaetas } \\
\text { Ungqul }\end{array}$ \\
\hline 0,5 & 1,20 & 1,20 & 1,10 & 1,10 \\
\hline 1 & 1,20 & 1,27 & 1,10 & 1,10 \\
\hline 1,5 & 1,32 & 1,33 & 1,10 & 1,05 \\
\hline 2 & 1,40 & 1,30 & 1,10 & 1,05 \\
\hline 2,5 & 1,35 & 1,30 & 1,10 & 0,95 \\
\hline 3 & 1,24 & 0 & 1,05 & 0 \\
\hline 3,5 & 1,12 & & 0,95 & \\
\hline 4 & $0^{4}$ & & 0 & \\
\hline
\end{tabular}

Table 2. Price of Palawija plant coefficient

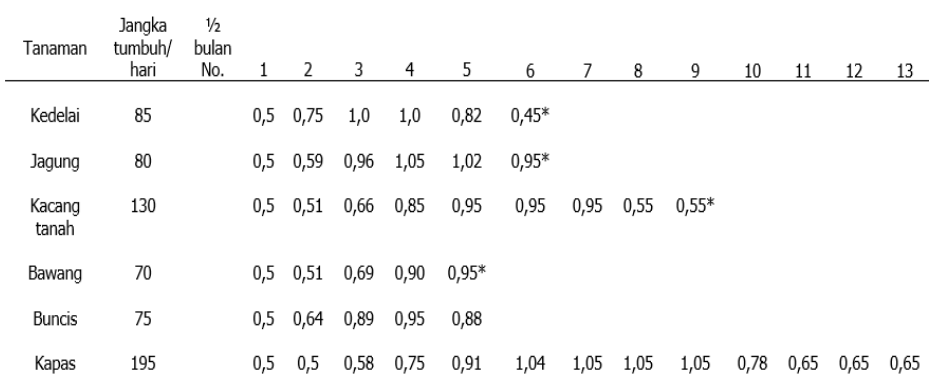




\section{Percolation and Seepage $(P)$}

The rate of percolation is very dependent on the properties of the soil. Data on percolation will be obtained from soil capability studies. The soil graduation test will be part of this investigation. (KP 01, 2013)

Based on the type of soil, the percolation power can be grouped into:

1. Sandy loam with percolation 3-6 $\mathrm{mm} /$ day

2. Loam with percolation power of $2-3 \mathrm{~mm} /$ day

3. Clay loam with a insulation power of $1-2 \mathrm{~mm} /$ day.

\section{Land Preparation}

For tertiary plots, the recommended time period for land preparation is 1.5 months. If land preparation is mainly carried out with machine tools, a period of one month can be considered. Land preparation. (KP 01, 2013)

Calculation of water requirements for land preparation is done by the Van de Goor Zijlstra method. This method is based on water requirements to replace water losses due to evaporation and percolation in paddy fields that have been saturated for 30 days with a height of inundation of $250 \mathrm{~mm}$, if there is a resting area of inundations of $300 \mathrm{~mm}$ or 8.33 $\mathrm{mm} /$ day.

$\mathrm{M}=\mathrm{E} 0+\mathrm{P}=1.1 \mathrm{ET0}+\mathrm{P}$

$\mathrm{Pd}=\llbracket \mathrm{Me} \rrbracket \wedge \mathrm{k} /\left(\mathrm{e}^{\wedge} \mathrm{k}-1\right)$

\section{Water layer replacement (WLR)}

After fertilization needs to be scheduled and replace the water layer as needed. Replacement is estimated at $50 \mathrm{~mm}$ each month and two months after transplantation (or $3.3 \mathrm{~mm} /$ day).

\section{Evapotranspiration Reference (ETo)}

Reference evapotranspiration (ETo) is the value of evapotranspiration of grass plants that spread over 8-15 cm in height, actively growing with enough water, to calculate the reference evapotranspiration (ETo), several methods can be used, namely:

1. Penman method,

2. the evaporation pan method

3. radiation method,

4. Blaney Criddle and method

5. Penman modification method

FAO (Suyono, 2003). Estimating the magnitude of crop evapotranspiration there are several stages that must be carried out, namely suspecting reference evapotranspiration; determine the coefficient of the plant then pay attention to local environmental conditions; such as climate variations at any time, altitude, land area, available groundwater, salinity, irrigation methods, and agricultural cultivation. Some methods for estimating reference evapotranspiration:

\section{Penman Modification Method}

The method used here is the Penman Modification method. To calculate ETO using the Penman modification method, the formulas used are:

$$
\begin{aligned}
& \text { es } \quad=611 \exp ((17,27 \mathrm{~T}) /(237,3+\mathrm{T})) \ldots \ldots . \text { (II.9) } \\
& \text { ed } \quad=\text { es } r \text {......................... (II.10) }
\end{aligned}
$$

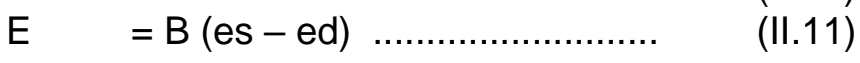

$$
\begin{aligned}
& \text { B }=\frac{0,102 u_{2}}{\left(\ln \left(\frac{Z_{2}}{Z_{0}}\right)\right)^{2}}
\end{aligned}
$$




\begin{tabular}{|c|c|c|}
\hline $\operatorname{Ln}$ & $=\sigma \mathrm{T} 4(0,56-0,092$ Ved $)(0,1+$ & $n / N)$ \\
\hline St & $=\mathrm{S} 0(\mathrm{a}+(\mathrm{b} \times \mathrm{n} / 12,1)) \ldots \ldots \ldots \ldots$ & (II. 1 \\
\hline Sn & 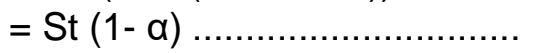 & (II. \\
\hline $\mathrm{Rn}$ & $=\mathrm{Sn}-\mathrm{Ln} \ldots \ldots \ldots \ldots$ & (II.1 \\
\hline IV & $=597,3-0,56 \mathrm{~T}$ & (II.1 \\
\hline En & $=\mathrm{Rn} /(\rho \mathrm{w} \mathrm{IV})$ & (II.18) \\
\hline ETO & $=(\beta E n+E) /(\beta+1)$. & (II.19 \\
\hline
\end{tabular}

\section{Consumptive Water Needs (ETC)}

Consumptive use is the amount of water used by plants for the photosynthesis of these plants. To calculate the water needs of plants in the form of evapotranspiration used:

$\mathrm{ETc}=\mathrm{Kc}$. Eto

Information :

Etc $=$ Evapotranspiration of plants ( $\mathrm{mm} /$ day)

Eto $=$ Evapotranspiration of reference plants ( $\mathrm{mm} /$ day)

Kc $=$ Average crop coefficient Source: (Sidharta, 1997)

\section{Mainstay Discharge}

Mainstay discharge is a reliable debit for a certain level of reliability or reliability. For irrigation purposes, reliable discharge is used with $80 \%$ reliability as specified in the Irrigation Planning Criteria. This means that $80 \%$ of the possible discharges that occur are greater or equal to the debit, or in other words, the irrigation system may fail once in five years. For the needs of drinking water and industry, higher reliability is required, which is around $90 \%$ to $95 \%$. If the river water is used for hydroelectric power generation, very high reliability is needed, which is between 95\% to 99\% (Kementerian PUPR Ditjen Sumber Daya Air, 2017).

\section{Mainstay Debit Calculation}

In this study the mainstay discharge analysis using FJ.Mock with the concept of water balance based on the 1973 hydrological cycle. Basically, the FJ Mock method is an analysis of the balance of monthly water discharge based on data on semi-monthly rainfall, evapotranspiration, soil moisture and groundwater storage. Some of them are lost due to evapotranspiration, some of them immediately turn into direct runoffs and some go into the ground or infiltrate. Where infiltration first saturates the surface of the ground then water percolation occurs and comes out as base flow. We can see the dependence between falling rainfall and evapotranspiration, infiltration, and total runoff which is a component of discharge.

The data or assumptions used in the FJ Mock calculation are:

A. 10-year Rainfall Data with rainfall stations which are considered to represent the condition of the area. The data needed is:

a) d average: 10-year average rainfall

b) $\mathrm{n}$ : Average number of 10 annual rainy days

(Agustin, 2011)

B. Restricted evapotranspiration is actual evapotranspiration by comparing the condition of vegetation and land surface and rainfall frequency.

a) Evapotranspiration (ETO) using the Penman Modification method ( $\mathrm{mm} /$ day)

b) Land opening factors used are:

- M $0 \%$ for land with dense forest

- M $10-40 \%$ for eroded land

- M 30-50\% for agricultural land though

c) $\mathrm{E}=\mathrm{ETO} \times(\mathrm{m} / 20(18-\mathrm{n})) \ldots \ldots . .$. 
: Number of average monthly rainy days

d) Limited evapotranspiration

$\mathrm{E} 1=\mathrm{ET} 0-\mathrm{E}$

C. Water Balance / water surplus is rainfall that has experienced evapotranspiration and filled soil storage. Water surplus directly affects the infiltration, percolation and total runoff which are components of the discharge.

a) $S=R-E 1$

b) Run-Off Storm $=10 \% \times R$

c) Soil Storage (IS) $=$ S - Run Off Storm

d) Water Surplus $=\mathbf{S}$ - Soil Storage

D. Run Off and Ground Water Storage

a) The coefficient I is found in the table

b) Infiltration $(I)=$ Ws $\times I$

c) The recession factor for groundwater $(\mathrm{K})$ is obtained from the following explanation:

- 0.5 For normal or normal rain catchment areas

- 0.8 for areas that have a small continuous flow

- 0.2 for regions that have a reliable continuous flow

d) Groundwater Storage

$(G S)=(0.5 \times I \times(1+K))+(K \times G s o m) \ldots$

e) $\Delta G S=G S-$ Gsom

f) Base Flow (BF) = Infiltration $-\triangle G S \ldots$.

g) Direct Run Off $(\mathrm{DRO})=$ Water Surplus - Infiltration .....

h) Run Off (RO) $=\mathrm{BF}+\mathrm{DRO}$

i) Watershed Area $(\mathrm{km} 2)=10000 \mathrm{ha}$

j) Mainstay discharge $=\mathrm{RO} \times$ Watershed $\times 1000(\mathrm{~m} 3 /$ month $)$

(Agustin, 2011)

The probability of being fulfilled is set at $80 \%$ (the possibility that the river discharge is lower than the main discharge is $20 \%)$. That possibility uses calculations

Q mainstay $80 \%=(0.8 \times$ Mainstay Debit) / (area DI) Itr / sec / ha .. (II.35)

Water balance $=Q$ mainstay $80 \%$ - DR intake (II.36)

\section{Irrigation Efficiency}

According in general water losses in irrigation networks can be divided as follows.

a. $12.5 \%-20 \%$ in tertiary channels

b. $5 \%-10 \%$ in the secondary channel

c. $5 \%-10 \%$ in the primary canal

(KP 03, 2013)

Efficiency in each plot is estimated as follows:

- Efficiency values in primary plots ranged from $92.5 \%-87.5 \%$.

- Efficiency values in secondary plots range from $92.5 \%-87.5 \%$

- Efficiency values in tertiary plots range from $85 \%-77.5 \%$.

(KP 01, 2013)

\section{Irrigation Water Needs}

Irrigation water demand is the amount of water volume needed to meet the needs of evapotranspiration, water loss, water needs for plants by paying attention to the amount of water provided by nature through rain and the contribution of groundwater. (Sidharta, 1997) The need for water in paddy fields for rice is determined by the following factors:

1. how to prepare the land 
2. water requirements for plants

3. percolation and seepage

4. Substitution of water layers, and

5. effective rainfall.

The total water demand in a paddy field (GFR) includes factors 1 to 4 . The net (net) demand for water in a paddy field (NFR) also takes into account effective rainfall. Calculation of irrigation water needs (NFR) can be done with the formula:

Rice NFR $=\mathrm{ETC}+\mathrm{Pd}+\mathrm{P}+\mathrm{WLR}-\mathrm{Re}$ (II.37)

NFR palawija / sugarcane $=\mathrm{ETC}-\mathrm{Re}$

Tertiary channel NFR / DR intake $=($ NFR (rice / secondary crops) $) /$ Eff ......

\section{Netto Debit}

To determine the dimensions of the channel, the planned capacity is calculated against the maximum discharge $Q=100 \% \times$ Maximum. The discharge plan for a channel is calculated using the following general formula (KP 05, 2013)

$\mathrm{Q}$ netto $=(\mathrm{NFR} \times \mathrm{A}) / \mathrm{Eff}=(\mathrm{NFR}$ tertiary channel or DR intake $) \times A$

\section{RESEARCH METHODOLOGY}

\section{Data Collection Methods}

Secondary data, where this data is obtained not through direct observation in the field. Included in this secondary data classification include supporting literature, graphs, tables and which are closely related to the process of analyzing cropping patterns. This secondary data includes:

1. Hydrological data for Kayu Aro, and Depati Parbo

2. Climatology data of Kayu Aro, and Depati Parbo

3. Topographic map of Kerinci Regency

\section{Research Location}

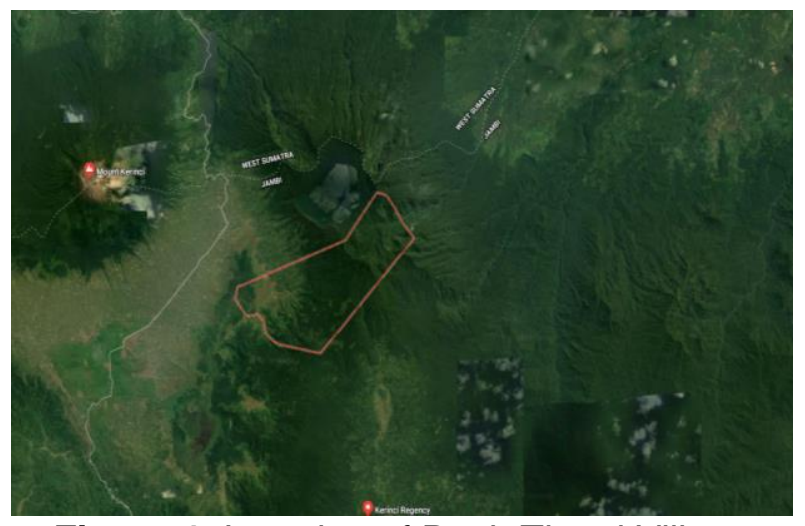

Figure 1. Location of Pauh Tinggi Village

The research location is located in Pauh Tinggi, Kerinci Regency, Jambi. The Pauh Tinggi Irrigation Area has an area of 473 ha of irrigation land, and is divided into 12 tertiary plots. The Pauh Tinggi irrigation area receives water from the dammed Batanghari River.

The location of the rain station is located in Kayu Aro, and Depati Parbo. Map coordinates as follows:

- Kayu Aro: $01^{\circ} 40$ '15 "LS and $101^{\circ} 40^{\prime} 20$ " East.

- Depati Parbo: $02^{\circ} 05$ '00' 'LS and $101^{\circ} 27^{\prime} 00$ " East 


\section{Data Management Stage}

This irrigation analysis stage includes:

a) Identification of problems and criteria

b) Secondary data collection

c) Analysis of climatological and hydrological data

d) Calculation of cropping patterns

e) Calculation of plant water requirements, and efficiency

f) Calculation of efficiency

g) Mainstay debit calculation

\section{Planning Data}

Each analysis requires data as a settlement to be carried out. The data is processed using the formula in accordance with the Irrigation Planning (KP) Criteria. The supporting data include:

\section{Topographic Map}

This topographic map is the topographic map of the Kerinci Regency, which was obtained from the Kerinci Regency Public Works Department. The Pauh Tinggi Irrigation Area has an area of 473 ha of irrigation land, and is divided into 12 tertiary plots. The Pauh Tinggi irrigation area receives water from the dammed Batanghari River.

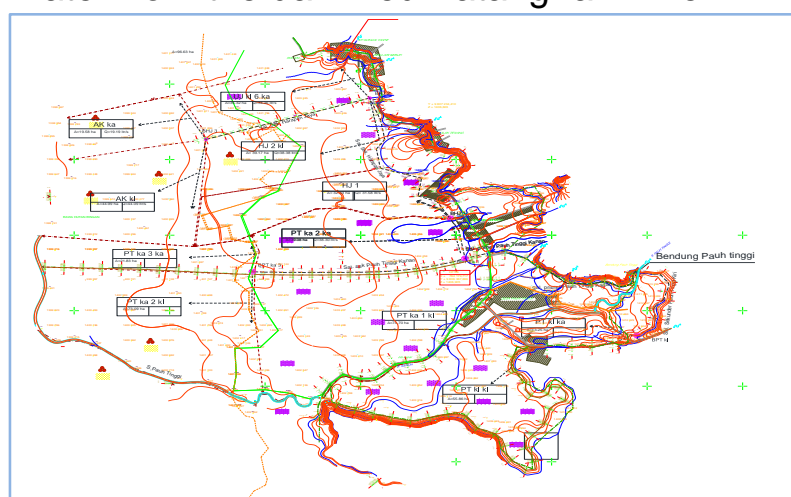

Figure 2. Lay Out Pauh Tinggi Irrigation Network

Table 3. DAS Batanghari River Condition

\begin{tabular}{|c|l|l|l|l|}
\hline No & \multicolumn{1}{|c|}{ Kondisi Iklim } & $\begin{array}{c}\text { DAS Batanghari } \\
\text { Hulu }\end{array}$ & $\begin{array}{c}\text { DAS } \\
\text { Batanghari } \\
\text { Tengah }\end{array}$ & $\begin{array}{c}\text { DAS } \\
\text { Batanghari } \\
\text { Hilir }\end{array}$ \\
\hline 1 & $\begin{array}{l}\text { Klasifikasi Iklim } \\
\text { (Schmidt\&Ferguson) }\end{array}$ & $\begin{array}{l}\text { Sangat Basah } \\
\text { (Af) }\end{array}$ & Basah (Am) & Basah (Am) \\
\hline 2 & Rata-rata bulan basah & 12 bulan & 10 bulan & 10 bulan \\
\hline 3 & Rata-rata bulan kering & Tidak ada & 1 bulan & 1 bulan \\
\hline 4 & Curah Hujan rata-rata & $3.000 \mathrm{~mm} / \mathrm{h}$ & $2.340 \mathrm{~mm} / \mathrm{th}$ & $2.271 \mathrm{~mm} / \mathrm{h}$ \\
\hline 5 & Jumlah hari hujan & 13 hari/bh & & \\
\hline 6 & Ketinggian tempat & $500-3.000 \mathrm{~m}$ dpl & $100-500 \mathrm{~m}$ dpl & $0-100 \mathrm{~m}$ dpl \\
\hline
\end{tabular}


Table 4. Provinces and Regencies in the DAS Batanghari River

\begin{tabular}{|c|c|c|c|}
\hline SUB DAS & Province & Large & Dastrict \\
\cline { 3 - 4 } $\begin{array}{c}\text { Batanghari } \\
\text { Hulu }\end{array}$ & $\begin{array}{c}\text { Jambi, } \\
\text { Sumatra } \\
\text { Barat, Riau }\end{array}$ & 1277947 & $\begin{array}{c}\text { Bungo, Tebo, Kerinci, Solok, } \\
\text { Sawahlunto, Sijunung, } \\
\text { Dharmasraya, Indragiri Hulu }\end{array}$ \\
\hline $\begin{array}{c}\text { Batang } \\
\text { Tebo }\end{array}$ & Jambi & 538725 & Bungo, Tebo, Kerinci \\
\hline $\begin{array}{c}\text { Batang } \\
\text { Tabir }\end{array}$ & Jambi & 381329 & $\begin{array}{c}\text { Merangin, Tebo, Batanghari, } \\
\text { Kerinci }\end{array}$ \\
\hline $\begin{array}{c}\text { Batang } \\
\text { Merangin }\end{array}$ & Jambi & 1281907 & $\begin{array}{c}\text { Batanghari, Sarolangun, } \\
\text { Merangin, Kerinci }\end{array}$ \\
\hline $\begin{array}{c}\text { Batanghari } \\
\text { Hilir }\end{array}$ & Jambi & 979559 & $\begin{array}{c}\text { Kota Jambi, Tebo, Tanjung, } \\
\text { Jabung Timur, Muaro Jambi, } \\
\text { Batanghari }\end{array}$ \\
\hline
\end{tabular}

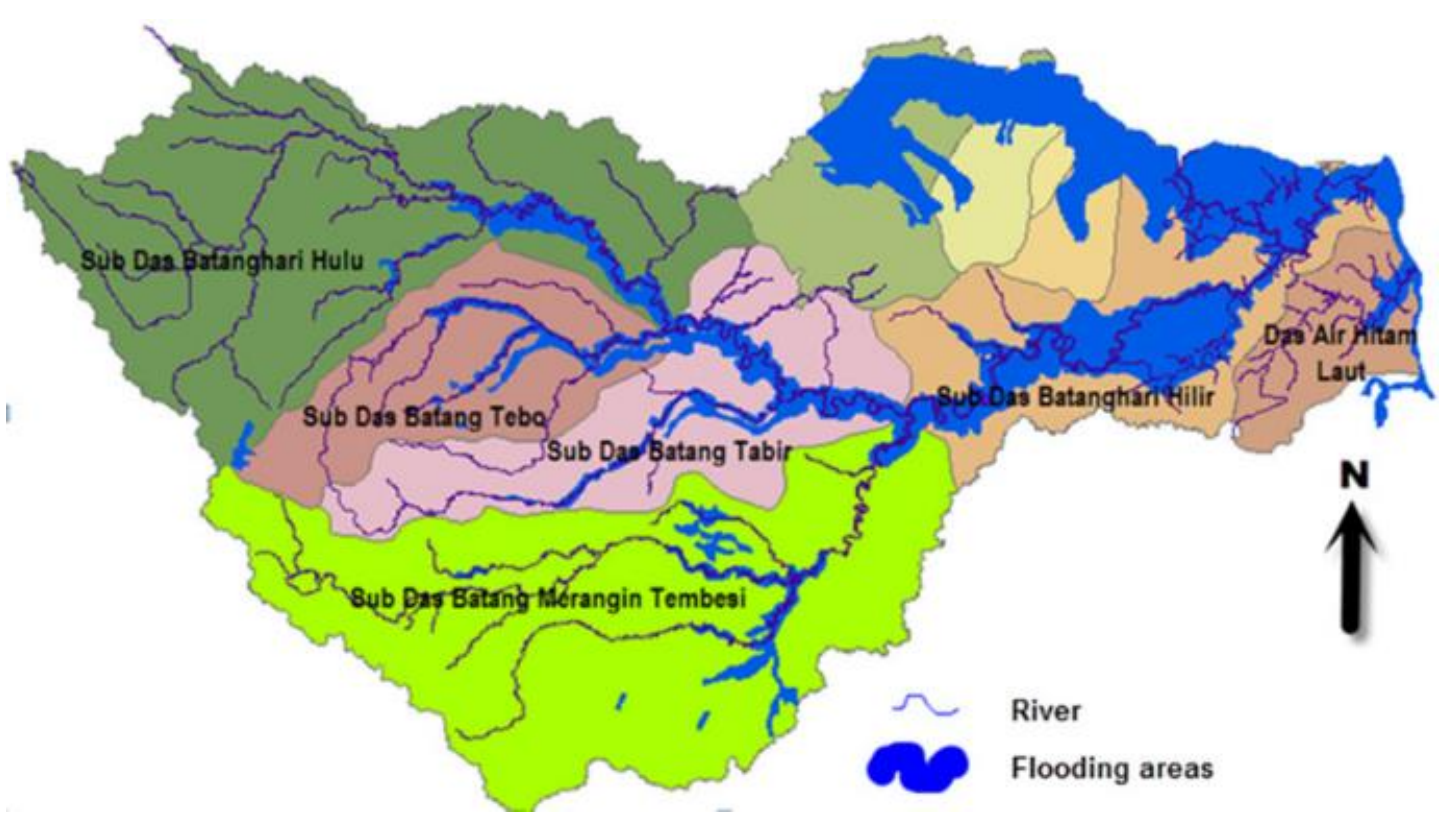

Figure 3. DAS Batanghari area

Data Hidrometri

Data Curah Hujan 2 stasiun terdekat dari lokasi perencanaan yaitu Stasiun Depati Parbo, dan Kayu Aro. Periode data yang diperlukan kurang lebih 10 tahun pada tahun $2009-2018$. Data ini diperoleh dari Dinas Pengairan Kabupaten Kerinci dan Badan Klimatologi dan Geofisika yang berguna untuk menghitung analisa hidrologi.

Data klimatologi

Data klimatologi tersebut berasal dari Stasiun Klimatologi Kayu Aro. Periode data yang diperlukan kurang lebih 10 tahun pada tahun 2007- 2016. Data ini diperoleh dari Dinas Pekerjaan Umum Kabupaten Kerinci, dan Badan Meteorologi dan Geofisika (BMKG).

Skema Jaringan Irigasi

Meliputi informasi saluran, petak tersier, keterangan luas area sawah, 


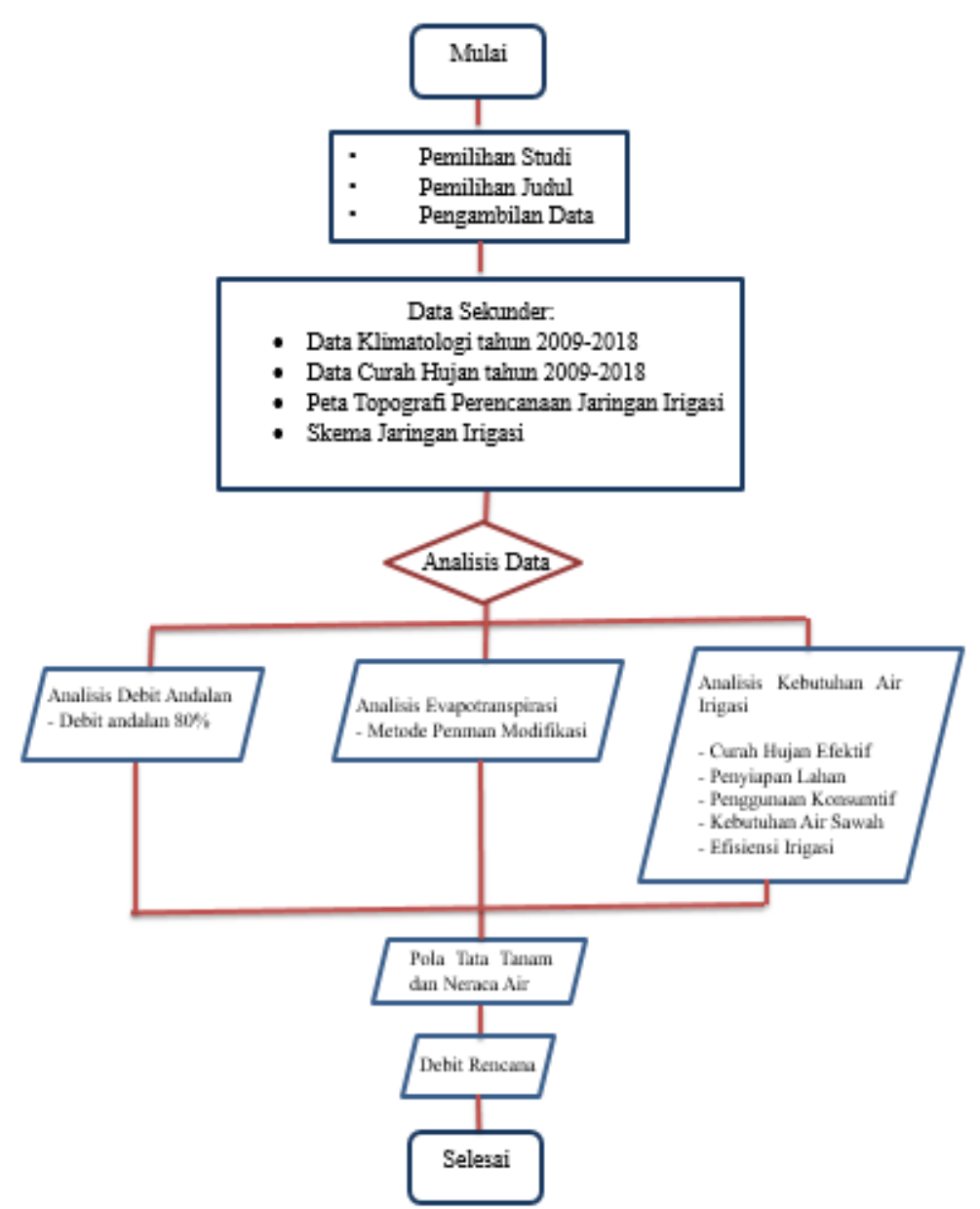

Figure 4. Flow diagram

\section{RESULTS AND DISCUSSION}

\section{Maximum Rainfall and Finding Missing Data}

Looking for maximum rainfall data for the Depati Parbo and Kayu Aro areas with 2 periods per month. There was missing data in May 2013 in the Depati Parbo area, so searching for lost data was done as follows:

$\mathrm{dx}=1 / \mathrm{n} x \Sigma[(\mathrm{d} / \mathrm{An} 1) \mathrm{x}$ Anx $] \mathrm{dx}$

Calculation of missing data for Depati Parbo rainfall in May 2013 period I:

$$
\begin{aligned}
\mathrm{dx} & =1 / 2 \times(24 / 25.05) \times 29.34 \\
& =14.06 \mathrm{~mm} / \text { day }
\end{aligned}
$$

Calculation of missing data for Depati Parbo rainfall in May 2013 period II:

$$
\begin{aligned}
\mathrm{dx} & =1 / 2 \times(32 / 33.6) \times 27.69 \\
& =13.19 \mathrm{~mm} / \text { day }
\end{aligned}
$$


Table 5. Searching for Lost Data of Depati Parbo in May 2013, period I and II

\begin{tabular}{|c|c|c|}
\hline \multirow{2}{*}{ Tahun } & \multicolumn{2}{|c|}{ Curah Hujan Bulan Mei Periode I (mm/ hari) } \\
\cline { 2 - 3 } & Depati Parbo & Kayu Aro \\
\hline 2018 & 43,30 & 100,00 \\
\hline 2017 & 63,70 & 9,00 \\
\hline 2016 & 30,20 & 9,50 \\
\hline 2015 & 12,60 & 17,00 \\
\hline 2014 & 22,80 & 27,00 \\
\hline 2013 & - & 24,00 \\
\hline 2012 & 27,60 & 45,00 \\
\hline 2011 & 11,30 & 0,00 \\
\hline 2010 & 40,00 & 19,00 \\
\hline 2009 & 12,60 & 0,00 \\
\hline Rata- Ra & \multicolumn{2}{|c|}{} \\
\hline \multicolumn{2}{|c|}{ Nilai data hilang Depati Parbo } & 14,057 \\
\hline \multicolumn{2}{|c}{}
\end{tabular}

\begin{tabular}{|c|c|c|}
\hline \multicolumn{2}{|c|}{ Nilai data hilang Depati Parbo } & 14,057 \\
\hline \hline \multirow{3}{*}{ Tahun } & Curah Hujan Bulan Mei Periode II (mm/ hari) \\
\cline { 2 - 3 } & Depati Parbo & Kayu Aro \\
\hline 2018 & 37,10 & 34,00 \\
\hline 2017 & 17,80 & 22,00 \\
\hline 2016 & 30,60 & 30,00 \\
\hline 2015 & 0,00 & 5,00 \\
\hline 2014 & 22,00 & 40,00 \\
\hline 2013 & - & 32,00 \\
\hline 2012 & 15,10 & 26,00 \\
\hline 2011 & 67,70 & 48,00 \\
\hline 2010 & 58,90 & 51,00 \\
\hline 2009 & 0,00 & 48,00 \\
\hline Rata- Ra & 27,69 & \\
\hline \multicolumn{2}{|c|}{ Nilai data hilang Depati Parbo } & 33,60 \\
\hline \multicolumn{2}{|}{} \\
\hline
\end{tabular}

Then it was obtained in May 2013 in the Depati Parbo area for period I which was 14,057 $\mathrm{mm} /$ day and untul period II which was $13,185 \mathrm{~mm} /$ day.

\section{Mainstay Rainfall}

Looking for Rainfall Mainstay monthly 2 periods: $R 80=n / 5+1=(10 / 5)+1=3$

The smallest data obtained for R80, so the data can be as follows:

CURAH HUJAN ANDALAN R80 PER 2 PERIODE

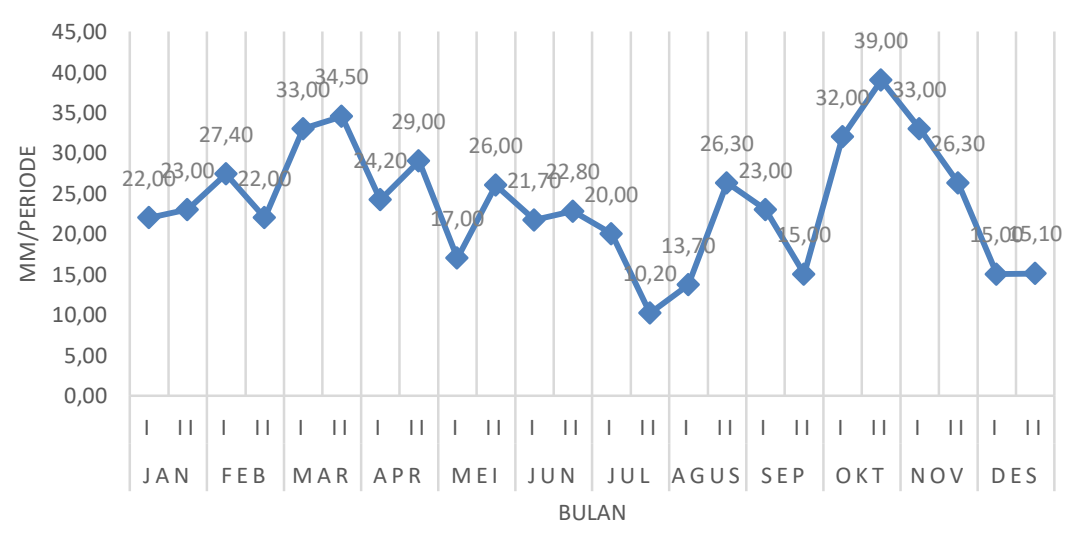

Figure 5. R80 Mainstay Rainfall Graph

In this graph it can be concluded that the mainstay rainfall (R80) which is mostly found in October period 2 with a value of $39.0 \mathrm{~mm} /$ period, while the few that are found in July period 
:: IJIEEB ::

(International Journal of Integrated Education, Engineering Business)

2 with a value of $10.2 \mathrm{~mm} /$ period.

\section{Effective Rainfall}

Effective rainfall using the Basic Years method in the first January period 1 is calculated by the analysis of the formula as follows:

$$
\begin{aligned}
\mathrm{R} 80 & =22.00(\mathrm{~mm} / \text { period }) / 15 \text { days } \\
& =1,467 \mathrm{~mm} / \text { day } \\
\text { Re palawija } & =50 \% . \mathrm{R} 80 \\
& =50 \% \cdot 1,467=1,006 \mathrm{~mm} / \text { day } \\
\text { Re rice } & =70 \% . R 80 \\
& =70 \% .1,467=1,027 \mathrm{~mm} / \text { day }
\end{aligned}
$$

Re Sugar cane $=60 \%$. R80

$$
=60 \% \cdot 1,467=1,027 \mathrm{~mm} / \text { day }
$$

Table 6. Effective Rainfall

\begin{tabular}{|c|c|c|c|c|r|r|}
\hline \multirow{2}{*}{ Bulan } & $\begin{array}{c}\text { Jumlah } \\
\text { Hari }\end{array}$ & $\begin{array}{c}\mathbf{R} 8 \mathbf{0} \\
\text { (mm/periode) }\end{array}$ & $\begin{array}{c}\text { Re80 } \\
\text { (mm/hari) }\end{array}$ & $\begin{array}{c}\text { Re Padi } \\
\text { (mm/hari) }\end{array}$ & $\begin{array}{c}\text { Re } \\
\text { Palawija } \\
\text { (mm/hari) }\end{array}$ & $\begin{array}{r}\text { Re tebu } \\
\text { (mm/hari) }\end{array}$ \\
\hline \multirow{2}{*}{ Januari } & 15 & 22,000 & 1,467 & 1,027 & 0,733 & 0,88 \\
\cline { 2 - 7 } & 16 & 23,000 & 1,438 & 1,006 & 0,719 & 0,862 \\
\hline \multirow{2}{*}{ Februari } & 15 & 27,400 & 1,827 & 1,279 & 0,913 & 1,096 \\
\cline { 2 - 7 } & 13 & 22,000 & 1,692 & 1,185 & 0,846 & 1,015 \\
\hline \multirow{2}{*}{ Maret } & 15 & 33,000 & 2,200 & 1,540 & 1,100 & 1,32 \\
\cline { 2 - 7 } & 16 & 34,500 & 2,156 & 1,509 & 1,078 & 1,293 \\
\hline \multirow{2}{*}{ April } & 15 & 24,200 & 1,613 & 1,129 & 0,807 & 0,968 \\
\cline { 2 - 7 } & 15 & 29,000 & 1,933 & 1,353 & 0,967 & 1,16 \\
\hline \multirow{2}{*}{ Mei } & 15 & 17,000 & 1,133 & 0,793 & 0,567 & 0,68 \\
\cline { 2 - 7 } & 16 & 26,000 & 1,625 & 1,138 & 0,813 & 0,975 \\
\hline \multirow{2}{*}{ Juni } & 15 & 21,700 & 1,447 & 1,013 & 0,723 & 0,868 \\
\cline { 2 - 7 } & 15 & 22,800 & 1,520 & 1,064 & 0,760 & 0,912 \\
\hline \multirow{2}{*}{ Juli } & 15 & 20,000 & 1,333 & 0,933 & 0,667 & 0,8 \\
\cline { 2 - 7 } & 16 & 10,200 & 0,638 & 0,446 & 0,319 & 0,382 \\
\hline \multirow{2}{*}{ Agustus } & 15 & 13,700 & 0,913 & 0,639 & 0,457 & 0,548 \\
\cline { 2 - 7 } & 16 & 26,300 & 1,644 & 1,151 & 0,822 & 0,986 \\
\hline \multirow{2}{*}{ September } & 15 & 23,000 & 1,533 & 1,073 & 0,767 & 0,92 \\
\cline { 2 - 7 } & 15 & 15,000 & 1,000 & 0,700 & 0,500 & 0,6 \\
\hline \multirow{2}{*}{ Oktober } & 15 & 32,000 & 2,133 & 1,493 & 1,067 & 1,28 \\
\cline { 2 - 7 } & 16 & 39,000 & 2,438 & 1,706 & 1,219 & 1,462 \\
\hline \multirow{2}{*}{ November } & 15 & 33,000 & 2,200 & 1,540 & 1,100 & 1,32 \\
\cline { 2 - 7 } & 15 & 26,300 & 1,753 & 1,227 & 0,877 & 1,052 \\
\hline \multirow{2}{*}{ Desember } & 15 & 15,000 & 1,000 & 0,700 & 0,500 & 0,6 \\
\cline { 2 - 7 } & 16 & 15,100 & 0,944 & 0,661 & 0,472 & 0,566 \\
\hline
\end{tabular}




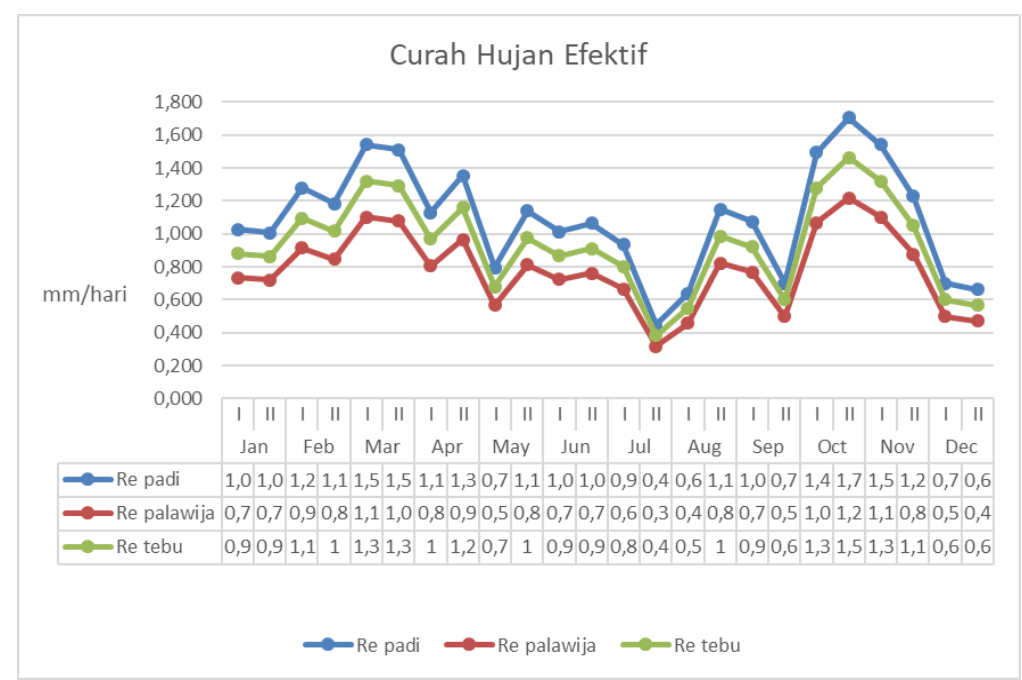

Figure 5. Effective Rainfall

From this graph it can be seen that the effective rainfall for rice (Re-paddy) is the largest, and the effective rainfall for the smallest (Re-cropping). The greatest effective rainfall is in the 20th or October period 2, while the smallest effective rainfall is in the 14th or July period 2.

\section{Calculating Potential Evapotranspiration (ETO)}

The method used here is the Penman Modification method because the climatology data is quite complete. Here are the results of the count for Evapotranspiration (ETO):

Calculate $E$ (Evaporation) from the values sought for ice (saturated water vapor pressure) and ed (water vapor pressure at elevation $2 \mathrm{~m}$ above the surface) and value B:

$$
\begin{aligned}
\text { es } & =611 \text { exp }((17.27 \mathrm{~T}) /(237.3+\mathrm{T})) \times 22.283) /(237.3+22.283)) \\
& =2690.71 \text { Pascal } \\
\text { ed } & =\text { es } \times \text { r (humidity) } \\
& =2690.71 \times 92.81 \% \\
& =2497,336 \text { Pascal } \\
& =18.71 \mathrm{mmHg} \\
\mathrm{B} & =\frac{0,102 u_{2}}{\left(\ln \left(\frac{Z_{2}}{Z_{0}}\right)\right)^{2}} \\
& =0.102 \times 2 /(\ln (5 / 200)) 2=0.023 \\
\mathrm{E} & =\mathrm{B}(\mathrm{es}-\mathrm{ed}) \\
& =0.023 \times(2690.71-2497.336) \\
& =4,434 \mathrm{~mm} / \text { day }
\end{aligned}
$$

$$
\begin{aligned}
\text { Coordinates } & =1040 ' 15 \text { "LS } \\
& =(1+40 / 60+15 / 3600) \text { o LS } \\
& =1,671 \text { o LS }
\end{aligned}
$$

Then calculated St (gross solar radiation absorbed by the earth's surface):

$$
\begin{aligned}
\mathrm{St} & =\mathrm{S} 0(\mathrm{a}+(\mathrm{b} \times \mathrm{n} / 12.1)) \\
& =885 \times(0.29+(0.42 \times 3.388 / 12.1) \\
& =360,721
\end{aligned}
$$

Calculates Sn (net solar radiation absorbed by the earth's surface) with the formula:

Sn $=$ St $(1-\alpha)$

The value of $\alpha=0.20$ is taken from the $\alpha$ (Albedo) Table in the form of plant surface type.

$\mathrm{Sn} \quad=360,721 \times(1-0,20)$ 


$$
=288.57 \text { (cal / cm2 / day) }
$$

Calculate Ln (long wave radiation emitted by the earth) with the formula:

$\mathrm{Ln} \quad=\sigma T 4(0.56-0.092 \sqrt{\text { ed }})(0.1+0.9 \mathrm{n} / \mathrm{N})$

$$
\begin{aligned}
& =1.17 .10-7 \times 295.284 \times(0.56-0.092 \sqrt{18.71}) \times(0.1+0.93 .388 / 12.1) \\
& =50,738(\mathrm{cal} / \mathrm{cm} 2 / \text { day })
\end{aligned}
$$

Calculate Iv (latent heat for evaporation) with the formula:

$$
\begin{aligned}
\text { IV } & =597.3-0.56 \mathrm{~T} \\
& =597.3-(0.56 \times 295,283) \\
& =584,733(\mathrm{cal} / \mathrm{gram})
\end{aligned}
$$

Calculate $\mathrm{Rn}$ (net radiation) with the formula:

$$
\begin{aligned}
\mathrm{Rn} & =\mathrm{Sn}-\mathrm{Ln} \\
& =288.57-50,738 \\
& =237,839(\text { cal } / \mathrm{cm} 2 / \text { day })
\end{aligned}
$$

Calculate En (Evaporation Depth) with the formula:

$$
\begin{aligned}
\mathrm{En} & =\mathrm{Rn} /(\rho \mathrm{w} \mathrm{lv}) \\
& =237,839 /(1 \times 584,733) \\
& =0.407(\mathrm{~mm} / \text { day })
\end{aligned}
$$

Calculate Potential Evapotranspiration (ET0) with the formula:

$\mathrm{ETO}=(\beta \mathrm{En}+\mathrm{E}) /(\beta+1)$

$B$ value obtained from Temperature interpolation is $22,2830 \mathrm{C}$ so $\beta$ with interpolation is 2,496 .

$$
\begin{aligned}
\text { ETO } & =((2.496 \times 0.407)+4,434) /(2,496+1) \\
& =4,172(\mathrm{~mm} / \text { day })
\end{aligned}
$$

\section{Grafik Evapotranspirasi Potensial ETO}

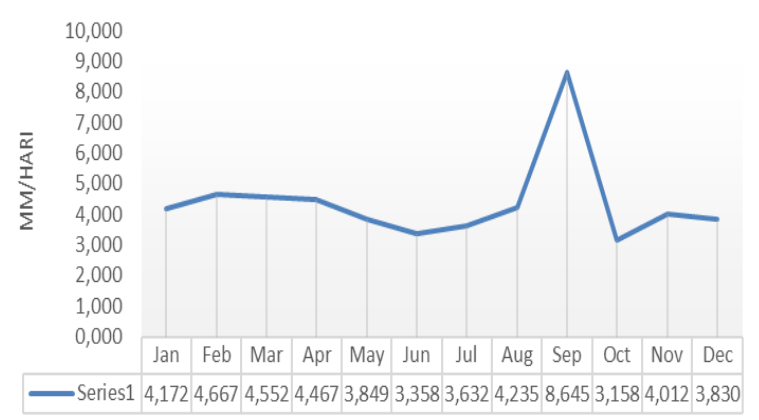

Figure 6. Potential Evapotranspiration Graph ETO

This graph shows the rate of evapotranspiration, the largest occurred in September 8,645 $\mathrm{mm} /$ day, the smallest occurred in October $3,158 \mathrm{~mm} /$ day.

\section{Land preparation}

Calculation of water requirements for land preparation is done by the Van de Goor Zijlstra method. This method is based on the need for water to replace water losses due to evaporation and percolation in paddy fields that have been saturated for 30 days with a high inundation of $250 \mathrm{~mm}$, or $8.33 \mathrm{~mm} /$ day. Calculating land preparation in January. Known in January:

$$
\begin{aligned}
& \text { Percolation }=2 \mathrm{~mm} / \text { day } \\
& \begin{aligned}
\text { Et0 } & =4.172 \\
\mathrm{M} & =\mathrm{E} 0+\mathrm{P}=1.1 \mathrm{ET0}+\mathrm{P} \\
& =1.1 \mathrm{ETO}+\mathrm{P} \\
& =(1.1 \times 4,172)+2 \\
& =6,590
\end{aligned}
\end{aligned}
$$




$$
\begin{aligned}
& =\llbracket \mathrm{Me} \rrbracket \wedge \mathrm{k} /\left(\mathrm{e}^{\wedge} \mathrm{k}-1\right) \\
& =(6,590.2,718 \rrbracket \wedge(6,590 \times 31 / 250) /(\llbracket 2,718 \rrbracket \wedge(6,590 \times 31 / 250)-1) \\
& =(6,590.2,718 \wedge 0,817 /(\llbracket 2,718 \rrbracket \wedge 0,817-1) \\
& =11,804 \mathrm{~mm} / \text { day }
\end{aligned}
$$

\begin{tabular}{|c|c|c|c|c|c|c|c|c|c|c|c|c|c|c|}
\hline \multicolumn{15}{|c|}{ Kebutuhan air untuk penyapan lahan ( Metode Van de Door dan Zijstra ) } \\
\hline \multirow[b]{2}{*}{ No. } & \multirow[b]{2}{*}{ Perhitungan } & \multicolumn{13}{|c|}{ Bulan } \\
\hline & & Satuan & Jan & Feb & Mar & Apr & Mei & Juni & Juli & Agst & Sep & $0 \mathrm{kt}$ & Nov & Des \\
\hline 1 & Eto & mm/hari & 4,172 & 4,667 & 4,552 & 4,467 & 3,849 & 3,358 & 3,632 & 4,235 & 8,645 & 3,158 & 4,012 & 3,830 \\
\hline 2 & Eo=1,1 x Eto & mm/hari & 4,590 & 5,134 & 5,008 & 4,913 & 4,234 & 3,694 & 3,996 & 4,659 & 9,509 & 3,474 & 4,414 & 4,212 \\
\hline 3 & & mm/hari & 2,00 & 2,00 & 2,00 & 2,00 & 2,00 & 2,00 & 2,00 & 2,00 & 2,00 & 2,00 & 2,00 & 2,00 \\
\hline 4 & $\mathrm{M}=\mathrm{E} 0+\mathrm{P}$ & mm/hari & 6,590 & 7,134 & 7,008 & 6,913 & 6,234 & 5,694 & 5,996 & 6,659 & 11,509 & 5,474 & 6,414 & 6,212 \\
\hline 5 & & hari & 31 & 28 & 31 & 30 & 31 & 30 & 31 & 31 & 30 & 31 & 30 & 31 \\
\hline 6 & & $\mathrm{~mm}$ & 250 & 250 & 250 & 250 & 250 & 300 & 250 & 250 & 250 & 250 & 250 & 250 \\
\hline 7 & $\mathrm{k}=\mathrm{MxT} / \mathrm{S}$ & & 0,817 & 0,799 & 0,869 & 0,830 & 0,773 & 0,569 & 0,743 & 0,826 & 1,381 & 0,679 & 0,770 & 0,770 \\
\hline 8 & & & 2,718 & 2,718 & 2,718 & 2,718 & 2,718 & 2,718 & 2,718 & 2,718 & 2,718 & 2,718 & 2,718 & 2,718 \\
\hline 9 & & & 2,264 & 2,223 & 2,384 & 2,292 & 2,166 & 1,767 & 2,103 & 2,283 & 3,979 & 1,971 & 2,159 & 2,160 \\
\hline 10 & $e^{k}-1$ & & 1,264 & 1,223 & 1,384 & 1,292 & 1,166 & 0,767 & 1,103 & 1,283 & 2,979 & 0,971 & 1,159 & 1,160 \\
\hline 11 & & mm/hari & 11,804 & 12,967 & 12,070 & 12,263 & 11,580 & 13,117 & 11,431 & 11,848 & 15,373 & 11,110 & 11,948 & 11,566 \\
\hline
\end{tabular}

Table 7. Land Requirement for Land Preparation (Pd) by Van De Goor and Zijlstra methods

\section{Water Layers Replacement (WLR)}

After fertilization needs to be scheduled and replace the water layer as needed. Replacement is estimated at $50 \mathrm{~mm}$ each month and two months after transplantation (or $3.3 \mathrm{~mm} /$ day).

\section{Percolation and Seepage (P)}

The rate of percolation is very dependent on the properties of the soil. Data on percolation will be obtained from soil capability studies. The soil graduation test will be part of this investigation. (KP 01, 2013)

Based on the type of soil in Pauh Tinggi, which is clay loam, the percolation rate is $2 \mathrm{~mm} /$ day.

\section{Consumptive Water Needs (ETC)}

Consumptive use is the amount of water used by plants for the photosynthesis of these plants. In the calculation of consumptive water needs this time used the calculation of the most efficient planting patterns, namely alternative planting patterns 14 in February to I.

Etc

\begin{tabular}{|c|c|c|c|c|c|c|c|c|c|c|c|c|c|c|c|c|c|c|c|c|c|c|c|c|c|c|}
\hline \multirow{2}{*}{ No } & \multirow{2}{*}{$\begin{array}{l}\text { Bulan } \\
\text { Periode }\end{array}$} & \multirow{2}{*}{ Satuan - } & \multicolumn{2}{|c|}{ Jamaraí } & \multicolumn{2}{|c|}{ Februari } & \multicolumn{2}{|c|}{ Maret } & \multicolumn{2}{|c|}{ April } & \multicolumn{2}{|c|}{ Mei } & \multicolumn{2}{|c|}{ Jumi } & \multicolumn{2}{|c|}{ Juli } & \multicolumn{2}{|c|}{ Agustus } & \multicolumn{2}{|c|}{ September } & \multicolumn{2}{|c|}{ Oktober } & \multicolumn{2}{|c|}{ Norember } & \multicolumn{2}{|c|}{ Desember } \\
\hline & & & I & II & I & II & I & II & I & II & $\mathrm{I}$ & II & I & II & $\mathrm{I}$ & II & $\mathrm{I}$ & II & $\mathrm{I}$ & II & I & II & $\mathrm{I}$ & II & I & II \\
\hline 1 & Pol Tata Tanam & & & & LP & & \multicolumn{6}{|c|}{ Padi umggoll190 hari } & Bero & & \multicolumn{6}{|c|}{ Jagumg 80 hari } & IP & & \multicolumn{4}{|c|}{ Padi unggul 90 hari } \\
\hline \multirow{2}{*}{2} & & & 1,300 & 0,000 & & & 1,200 & 1,270 & 1,330 & 1,300 & 1,300 & 0,000 & & & 0,500 & 0,590 & 0,960 & 1,050 & 1,020 & 0,550 & & & 1,200 & $\mid 1,270$ & 1,330 & 1,300 \\
\hline & & & 1,300 & 1,300 & 0,000 & & & 1,200 & 1,270 & 1,330 & 1,300 & 1,300 & 0,000 & & & 0,500 & 0,590 & 0,960 & 1,050 & 1,020 & 0,950 & & & 1,200 & 1,270 & 1,330 \\
\hline 3 & Rata-Rata Koefsisen Tanamanan & & 1,300 & 0,550 & 0,000 & 0,000 & 0,000 & 1,235 & 1,300 & 1,315 & 1,300 & 0,650 & 0,000 & 0,000 & 0,250 & 0,545 & 0,775 & 1,005 & 1,035 & 0,985 & 0,475 & 0,000 & 0,600 & 1,235 & 1,300 & 1,315 \\
\hline 4 & Evaporasi Potensial (ETO) & mmlhr & 4,172 & 4,172 & 4,667 & 4,667 & 4,552 & 4,552 & 4,467 & 4,467 & 3,849 & 3,449 & 3,358 & 3,358 & 3,632 & 3,632 & 4,2354 & 4,235 & 8,645 & 8,645 & 3,1583 & 3,158 & 4,012 & 4,012 & 3,830 & 3,830 \\
\hline 5 & Pengoumaan Air Konsunutif (Ecc) & mmlhr & 5,424 & 2,712 & 0,000 & 0,000 & 2,331 & 5,622 & 5,807 & 5,874 & 5,004 & 2,502 & 0,000 & 0,000 & 0,008 & 1,980 & 3,282 & 4,256 & 8,947 ] & 8,515 & 1,500 & 0,000 & 2,407 & 4,955 & 4,978 & 5,036 \\
\hline 6 & Rasio Luas (Etc) & & 1,000 & 1,000 & 1,000 & 0,750 & 0,250 & 0,250 & 0,750 & 1,000 & 1,000 & 1,000 & 1,000 & 0,750 & 0,250 & 0,250 & 0,750 & 1,000 & 1,000 & 1,000 & 1,000 & 0,750 & 0,250 & 0,250 & 0,750 & 1,000 \\
\hline 7 & Etc* Rasio Luas & mmhr & 5,424 & 2,712 & 0,000 & 0,000 & 0,683 & 1,406 & 4,355 & 5,874 & 5,004 & 2,502 & 0,000 & 0,000 & 0,227 & 0,495 & 2,462 & 4,256 & 8,477 & 8,515 & 1,500 & 0,000 & 0,002 & 1,239 & 3,734 & 5,036 \\
\hline
\end{tabular}

$$
\begin{array}{ll}
\text { Etc } & =\text { Kc. Eto } \\
& =((1.3+0) / 2) \times 4,667 \\
& =3.034 \mathrm{~mm} / \text { day } \\
\text { ETc Area Ratio } & =1.00
\end{array}
$$$$
\text { ETc } \times \text { Area Ratio ETc }=3.034 \times 1.00=3.034 \mathrm{~mm} / \text { day }
$$

Table 8. Consumptive Water Needs (ETc) 


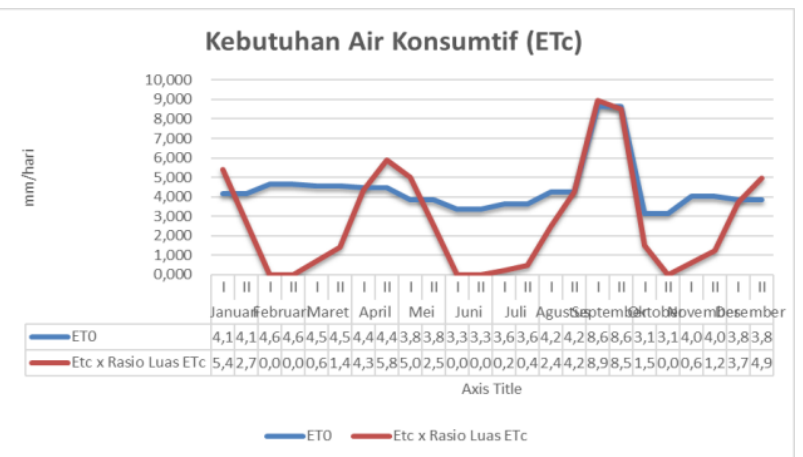

Figure 7. Consumptive Water Needs (ETc) Graph

This graph shows that the largest rate of ETC consumptive water demand was in September I with a value of $8.94 \mathrm{~mm} /$ day, while the lowest was in February, June, and October II with a value of $0.00 \mathrm{~mm} /$ day because at that time, and land preparation. As for the greatest ET0 water demand is in September I with a value of $8.6 \mathrm{~mm} /$ day, and the smallest in June with a value of $3.3 \mathrm{~mm} /$ day.

\section{Irrigation Water Needs and Irrigation Efficiency}

Calculation of irrigation water needs (NFR) can be done with the formula:

NFR Rice

$$
=\mathrm{ETC}+\mathrm{Pd}+\mathrm{P}+\mathrm{WLR}-\mathrm{Re}
$$

NFR palawija / sugar cane $=\mathrm{ETC}-\mathrm{Re} \ldots$

Tertiary channel NFR / DR intake $=($ NFR (rice / secondary crops)) $/$ Eff

According in general water losses in irrigation networks can be divided as follows.

a. $12.5 \%-20 \%$ in tertiary channels

b. $5 \%-10 \%$ in the secondary channel

c. $5 \%-10 \%$ in the primary canal

Efficiency in each plot is estimated as follows:

- Efficiency values in primary plots ranged from $92.5 \%-87.5 \%$. Taken $90 \%$

- Efficiency values in secondary plots ranged from $92.5 \%-87.5 \%$. Taken $90 \%$

- Efficiency values in tertiary plots range from $85 \%-77.5 \%$. Taken $80 \%$

In the calculation of irrigation water requirements for rice, the calculation of the most efficient planting pattern is used, which is the alternative planting pattern of 14 in February 1.

NFR Rice $=(3,034 \times 1.0)+(12,967 \times 0)+(2.0 \times 1.0)+(3,333 \times 0.25)-1,279$

$$
=4.59 \mathrm{~mm} / \text { day }
$$

NFR of tertiary rice plots

$$
\begin{aligned}
& =4.59 / 0.8 \\
& =5,736 \mathrm{~mm} / \text { day } \\
& =0.664 \mathrm{It} / \mathrm{sec} / \mathrm{ha} \\
& =0.664 /(0.9 \times 0.9) \\
& =0.82 \mathrm{It} / \mathrm{sec} / \mathrm{ha}
\end{aligned}
$$

Rice intake DR

In the calculation of irrigation water needs for secondary crops used the calculation of the most efficient cropping patterns, namely alternative cropping patterns 14 in August II.

\begin{tabular}{|c|c|c|c|c|c|c|c|c|c|c|c|c|c|c|c|c|c|c|c|c|c|c|c|c|c|c|}
\hline \multirow{2}{*}{ No } & \multirow{2}{*}{$\begin{array}{c}\text { Bulan } \\
\text { Periode } \\
\end{array}$} & \multirow[b]{2}{*}{ Satuan } & \multicolumn{2}{|c|}{ Jan } & \multicolumn{2}{|c|}{ Feb } & \multicolumn{2}{|c|}{ Mar } & \multicolumn{2}{|c|}{ Apr } & \multicolumn{2}{|c|}{ M ay } & \multicolumn{2}{|c|}{ Jun } & \multicolumn{2}{|c|}{ Jul } & \multicolumn{2}{|c|}{ Aug } & \multicolumn{2}{|c|}{ Sep } & \multicolumn{2}{|c|}{ Oct } & \multicolumn{2}{|c|}{ Nov } & \multicolumn{2}{|c|}{ Dec } \\
\hline & & & \begin{tabular}{|l|}
$\mathbf{I}$ \\
\end{tabular} & II & I & $\bar{T}$ & I & $\sqrt{1}$ & - & 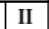 & $T$ & $\mathrm{JI}$ & I & I & \begin{tabular}{l|l} 
I \\
\end{tabular} & II & 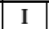 & 3 & 7 & II & $\bar{J}$ & II & I & II & I & II \\
\hline 1 & & ha & 1,30 & 1,29 & 0,66 & 51 & 1,16 & 26 & 1,10 & 1,05 & 1,27 & 1,26 & 0,62 & 0,11 & $-0,02$ & $-0,01$ & 0,22 & 0,37 & 1,10 & 1,04 & 0,07 & 0,23 & 1,07 & 1,28 & 1,05 & 1,03 \\
\hline 2 & & ha & 1,60 & 1, & 2 & 0,64 & 1 & 6 & 1,35 & 1,30 & 1,57 & 1,55 & 0,77 & 0,13 & $-0,03$ & $-0,02$ & 0,23 & 0,38 & 1,36 & 1,47 & \begin{tabular}{|l|}
0,29 \\
\end{tabular} & 0,39 & 1,33 & 1,58 & 1,29 & 1,28 \\
\hline
\end{tabular}

NFR of palawija $\quad=(3,282 \times 1,00)-1,15$

$$
=1.88 \mathrm{~mm} / \text { day }
$$

NFR of tertiary palawija plot $=1.151 / 0.8$

$$
\begin{aligned}
& =2,665 \mathrm{~mm} / \text { day } \\
& =0.308 \mathrm{It} / \mathrm{sec} / \mathrm{Ha}
\end{aligned}
$$

DR intake Rice $=0.308 /(0.9 \times 0.9) \quad=0.381 \mathrm{It} / \mathrm{sec} / \mathrm{ha}$

Table 9. Irrigation Water Needs in Tertiary and Intake Plots 


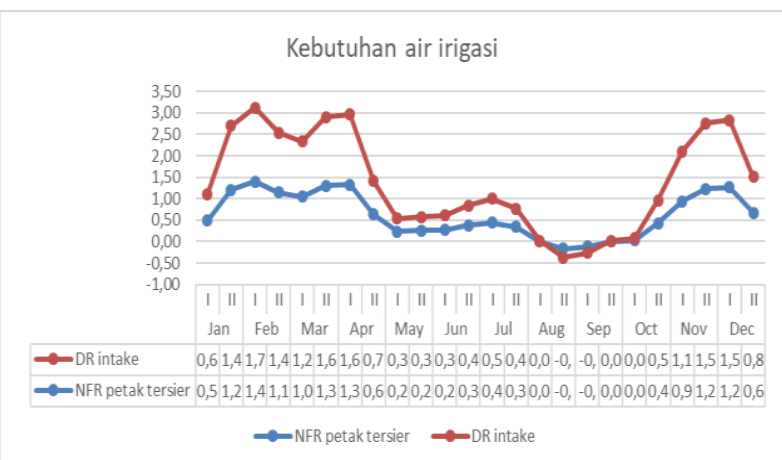

Figure 8. Irrigation Water Needs in Tertiary and Intake Plots

In this graph it can be stated that in February I was the time when the maximum irrigation water needs was tertiary NFR plots $=1.40 \mathrm{ltr} / \mathrm{sec} / \mathrm{ha}$ and DR intake $=1.72 \mathrm{ltr} / \mathrm{sec} / \mathrm{ha}$. Whereas in August II and September I with the results of tertiary NFR plots $=-0.02 \mathrm{ltr} / \mathrm{sec} /$ ha and DR intake $=-0.03 \mathrm{Itr} / \mathrm{sec} /$ ha which means surplus water, so that no irrigation is needed.

\section{Mainstay Debit Calculations}

The data or assumptions used in the FJ Mock calculation are:

A. 10-year Rainfall Data with rainfall stations which are considered to represent the condition of the area. The data needed is:

a) d average: 10-year average rainfall

b) $n$ : Average number of 10 annual rainy days

Calculates the average rainfall and the number of 10 yearly average rainy days in the Depati Parbo area in January.

$\mathrm{D}$ average $=(1.22+4.55+6.51+6.01+3.94+5.45+1.57+2.65+3 . .89+2.88) / 10$ $=3.87 \mathrm{~mm} /$ day

$\mathrm{n}$

$$
\begin{aligned}
& =(9+16+20+22+20+16+5+12+16+17) / 10 \\
& =15.3
\end{aligned}
$$

Table 10. Depati Parbo Average Rainfall

\begin{tabular}{|c|r|r|r|r|r|r|r|r|r|r|r|r|}
\hline \multirow{2}{*}{ Depati Parbo } & \multicolumn{10}{|c|}{ Rekapitulasi Curah Hujan Rata-Rata pada Bulan (mm/hari) } \\
\cline { 2 - 14 } & \multicolumn{1}{|c|}{ Jan } & \multicolumn{1}{|c|}{ Feb } & \multicolumn{1}{|c|}{ Mar } & \multicolumn{1}{|c|}{ Apr } & Mei & Jun & Jul & Agus & Sep & 0kt & Nov & Des \\
\hline CH rata & 3,87 & 6,22 & 5,75 & 6,12 & 4,35 & 3,13 & 3,13 & 3,63 & 3,00 & 4,11 & 7,18 & 5,06 \\
\hline Jumlah Hari Hujan & 15,30 & 14,30 & 16,50 & 17,80 & 16,60 & 11,80 & 9,50 & 11,80 & 12,00 & 14,90 & 21,40 & 19,60 \\
\hline Jumlah Curah Hujan & 119,87 & 174,05 & 178,32 & 183,49 & 134,77 & 93,76 & 97,02 & 112,42 & 90,02 & 127,47 & 215,46 & 156,93 \\
\hline
\end{tabular}

Calculate average rainfall and number of 10 yearly average rainy days in the Kayu Aro area in January.
D average
$=(0.48+5.97+4.88+1.97+6.40+6.52+2.68+7.02+8.89+7.02) / 10$
$=5.18 \mathrm{~mm} / \mathrm{day}$
$\mathrm{n}$$$
=(2+10+8+10+11+17+6+10+22+10) / 10
$$$$
=10.6
$$ 
Table 11. Kayu Aro Average Rainfall

\begin{tabular}{|c|c|c|c|c|c|c|c|c|c|c|c|c|}
\hline \multirow[t]{2}{*}{ Kayu Aro } & \multicolumn{12}{|c|}{ Rekapitulasi Curah Hujan Rata-Rata pada Bulan (mm/hari) } \\
\hline & Jan & Feb & Mar & Apr & Mei & Jun & Jul & Agus & Sep & $0 \mathrm{kt}$ & Nor & Des \\
\hline CHrata & 5,18 & 5,71 & 6,79 & 6,75 & 5,35 & & 3,33 & 3,44 & 4,76 & 7,25 & 7,5 & 4,4 \\
\hline Jumlah Hari Hujan & 10,6 & 11,1 & 14,1 & 14,1 & 10,9 & 8,8 & 8,9 & 9,7 & 10,8 & 16,1 & 15,6 & 11,5 \\
\hline Jumlah Curah Hujan & 160,66 & 159,96 & 210,41 & 202,39 & 165,8 & $\mid 119,98$ & 103,15 & 106,75 & 142,65 & 224,7 & 224,94 & 136,5 \\
\hline
\end{tabular}

D average (Kayu Aro + Depati Parbo $)=(3.87+5.18) / 2$

n (Kayu Aro + Depati Parbo)

$$
\begin{aligned}
& =4.52 \mathrm{~mm} / \text { day } \\
& =(15.3+10.6) / 2 \\
& =12.95
\end{aligned}
$$

Table 12. Average Rainfall of Aro Wood and Parbo Depati

\begin{tabular}{|c|r|r|r|r|r|r|r|r|r|r|r|r|}
\hline \multirow{2}{*}{$\begin{array}{c}\text { Kayu Aro/ Depati } \\
\text { Parbo }\end{array}$} & \multicolumn{10}{|c|}{ Rekapitulasi Curah Hujan Rata-Rata pada Bulan (mm/hari) Kayu Aro dan Depati Parbo } \\
\cline { 2 - 12 } & Jan & Feb & Mar & Apr & Mei & Jun & Jul & Agus & Sep & 0kt & Nov & Des \\
\hline CH rata & 4,52 & 5,9 & 6,27 & 6,43 & 4,85 & 3,56 & 3,23 & 3,54 & 3,88 & 5,68 & 7,34 & 4,73 \\
\hline Jumlah Hari Hujan & 12,95 & 12,70 & 15,30 & 15,95 & 13,75 & 10,30 & 9,20 & 10,75 & 11,40 & 15,50 & 18,50 & 15,55 \\
\hline Jumlah Curah Hujan & 140,27 & 167,01 & 194,37 & 192,94 & 150,29 & 106,87 & 100,09 & 109,59 & 116,34 & 176,09 & 220,20 & 146,72 \\
\hline
\end{tabular}

B. Restricted evapotranspiration is actual evapotranspiration by comparing the condition of vegetation and land surface and rainfall frequency.

a) Evapotranspiration (ET0) uses the Penman Modification method ( $\mathrm{mm} /$ day) with results.

b) Land opening factors used are:

- M 30-50\% for tillage (taken 40\%)

c) Calculate $E$ in January

$\mathrm{E}=\mathrm{ETO} \times(\mathrm{m} / 20(18-\mathrm{n}))$

$=4,172 \mathrm{~mm} /$ day $\times(40 \% / 20(18-12.95))$

$=129.34 \mathrm{~mm} /$ month $\times(40 \% / 20(18-12.95))$

Information:

$$
=13.06 \mathrm{~mm} / \text { month }
$$

ETO: Evapotranspiration

$\mathrm{m}$ : The coefficient that depends on the type of cloud and season

$\mathrm{n}$ : Average number of monthly rainy days

d) Limited evapotranspiration
$\mathrm{E} 1=\mathrm{ETO}-\mathrm{E}$
$=129.34-13.06$
$=116.28 \mathrm{~mm} /$ month

C. Calculating Water Balance / water surplus in January:

a) $\mathrm{S}=\mathrm{R}-\mathrm{E} 1$

$=140.27-116.28$

$=23.99 \mathrm{~mm} /$ month

b) Run Off Storm $\quad=10 \% \times \mathrm{R}$

$=10 \% \times 140.27$

$=14,027 \mathrm{~mm} /$ month

c) Soil Storage (IS) $=$ S - Run Off Storm

$=23.99-14,027$

$=9.96 \mathrm{~mm} /$ month

d) Water Surplus = S - Soil Storage $S$ - Soil Storage

$=23.99-9.96$

$=14.03 \mathrm{~mm} /$ month 
IS: Soil Storage

Text: Soil Moisture

There are two conditions to determine SMS, namely:

- SMS = $200 \mathrm{~mm} /$ month, if $(\mathrm{R}-\mathrm{E} 1)>0$

- SMS = SMS of the previous month $+(R-E 1)$, if $R-E 1<0$

D. Run Off and Ground Water Storage

a) The coefficient $i$ is obtained in Table. Run-off coefficient of various catchment conditions (DAS) is $50 \%$ :

b) Infiltration (I) = Ws $\times I$

$$
\begin{aligned}
& =14.03 \times 50 \% \\
& =7.015 \mathrm{~mm} / \text { month }
\end{aligned}
$$

c) The recession factor for groundwater $(K)$ is obtained from the following explanation:

- 0.5 For normal or normal rain catchment areas

d) Ground water Storage

$(\mathrm{GS})=(0.5 \times \mathrm{I} \times(1+\mathrm{K}))+(\mathrm{K} \times \mathrm{Gsom}$

$$
\begin{aligned}
& =0.5 \times 7.01 \times(1+0.50))+(0.50 \times 12.36) \\
& =11.44
\end{aligned}
$$

e) $\Delta \mathrm{GS} \quad=\mathrm{GS}$ - Gsom

$$
\begin{aligned}
& =11.44-12.36 \\
& =-0.92
\end{aligned}
$$

f) Base Flow (BF) = Infiltration $-\Delta \mathrm{GS}$

$$
\begin{aligned}
& =7,015-(-0.92) \\
& =7.94 \mathrm{~mm} / \text { month }
\end{aligned}
$$

g) Direct Run Off (DRO) = Water Surplus - Infiltration

$$
=14.03-7.01
$$

h) Run Off $(\mathrm{RO}) \quad$ ( BF $+\mathrm{DRO})$

$$
=7.015 \mathrm{~mm} / \text { month }
$$$$
=7.94+7,015
$$$$
=14.95 \mathrm{~mm} / \text { month }
$$

i) Watershed Area (km2) = $12779.47 \mathrm{~km} 2 \times 10000=1277947 \mathrm{Ha}($ II.40)

j) Mainstay discharge $=\mathrm{RO} \times$ Watershed $\times 1000$ (m3/ month)

$$
\begin{aligned}
& =14.95 \times 1277947 \times 1000 \\
& =191032930.50 \mathrm{~m} 3 / \text { month } \\
& =71.32 \mathrm{~m} 3 / \mathrm{s} \\
& =71323.53 \mathrm{It} / \mathrm{sec}
\end{aligned}
$$

The probability of being fulfilled is set at $80 \%$ (the possibility that the river discharge is lower than the main discharge is $20 \%$ ). That possibility uses calculation $\mathrm{k}$ ) $\mathrm{Q}$ mainstay $80 \%=$ (0.8 x Mainstay Debit) / (area DI) Itr / sec / ha

$$
\begin{aligned}
& =0.8 \times 71323.53 / 473 \\
& =120.63 \mathrm{liter} / \mathrm{sec} / \mathrm{ha}
\end{aligned}
$$




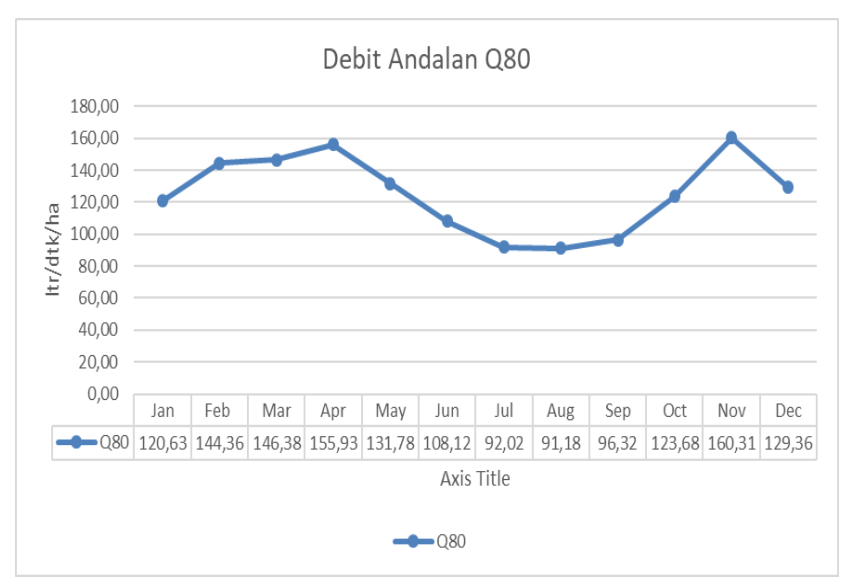

Figure 9. Q80 Mainstay Debit Chart

The graph above shows $80 \%$ Mainstay Debit for irrigation (Q80) which shows the availability of abundant water and can be used more optimally for community needs other than irrigation in the Pauh Tinggi area with maximum results in November Q80 $=160.31 \mathrm{ltr} / \mathrm{sec} / \mathrm{ha}$, and the minimum in August with $\mathrm{Q} 80=91.18$ liters $/ \mathrm{sec} / \mathrm{ha}$.

\section{Planting Patterns and Water Balance}

Planting pattern is the most important way in planting system planning. The purpose of holding a planting system is to set the time, place, type and area of plants in the irrigation area. The purpose of the planting system is to utilize the irrigation water supply as effectively and efficiently as possible so that the plants can grow well. The biggest factor in cropping patterns can be said to be efficient and optimal is if the water needs are fulfilled by a reliable discharge (water balance). The following is the calculation of the water balance in the alternative cropping pattern from January 14 to $\mathrm{I}$.

Note: Mainstay $80 \% \mathrm{Q}=120.63 \mathrm{liter} / \mathrm{sec} / \mathrm{ha}$

DR intake $\quad=1.60 \mathrm{Itr} / \mathrm{sec} / \mathrm{ha}$

Water balance $\quad=\mathrm{Q}$ mainstay $80 \%-\mathrm{DR}$ intake

$=120.63-1.60$

$=119.03 \mathrm{Itr} / \mathrm{dt}$.ha (fulfilled)

In this final project 17 alternative cropping patterns are made, and based on the water balance, alternative cropping patterns 14 are displayed which are the most efficient and optimal planting system. Other alternative cropping patterns that have been made are attached to the Appendix.

Alternative cropping patterns $14=$

Nedeco / Prosida superior rice

Nedeco / Prosida superior rice

Corn

\section{Netto Debit}

To determine the dimensions of the channel, the planned capacity is calculated against the maximum discharge $Q=100 \% \times$ Maximum. The calculated discharge is based on the results of the alternative planting pattern 14 and in January to $I$.

Qnetto $=($ NFR $\times$ A) / Eff $=($ NFR tertiary channel $/$ DR intake $) \times A$

Hope Jaya Jaya Secondary Channel and Irrigation Building BHJ 3 are known with:

Tertiary channel NFR $\quad=1.30 \mathrm{ltr} / \mathrm{sec} / \mathrm{ha}$

A tertiary plot of $\mathrm{AK} \mathrm{ki} \quad=45 \mathrm{ha}$

A tertiary plot of AK ka $\quad=19.60 \mathrm{ha}$ 
Qt Tertiary Plots AK ki $=1.30 \times 45=58.33$ liter $/ \mathrm{sec}$

Qt Tertiary plot $A K=1.30 \times 19.60=25.41$ liter $/ \mathrm{sec}$

Irrigation building BHJ $3=(58.33+25.41) /$ eff $=(58.33+25.41) / 0.9=93.1$ liter $/ \mathrm{sec}$

Qt sek Harapan Jaya 2 = BHJ $3=93.1$ liter $/ \mathrm{sec}$

Pauh Tinggi Dam is known by:

DR intake = $1.60 \mathrm{Itr} / \mathrm{sec} / \mathrm{ha}$

A total $=473$ ha

Qnetto DR intake $=1.60 \times 473=756.95$ liter $/ \mathrm{sec}$

\section{CONCLUSIONS}

From the calculation of irrigation water needs, water availability, and cropping patterns of the Pauh Tinggi Irrigation Area it can be concluded that:

1. Calculation of 17 alternative cropping patterns with different types of plant variants and different initial planting plans by comparing with the existing discharge factor (Q80). It was found that the planting pattern is very possible to always use the PADIPADI-PALAWIJA planting system because of the abundant water availability. After trying 17 alternative cropping patterns, the most efficient and optimal way is to obtain alternative planting patterns 14 in the form of PADI-PADI-CORN starting with land preparation in October II and February II, planting rice in November II and March II, planting corn in May I, and a land rest period (bero) in May II - June I

2. Based on Alternative Planting Pattern 14 which is the most efficient planting pattern, the amount of irrigation water demand in tertiary plots (NFR tertiary plots) ranges from 0 - $1.30 \mathrm{ltr} / \mathrm{sec} /$ ha with a maximum of $1.30 \mathrm{ltr} / \mathrm{sec} /$ ha in January l, while the need for irrigation water in the intake (DR intake) ranges from $0-1.60 \mathrm{ltr} \mathrm{sec} / \mathrm{ha}$ with a maximum of $1.60 \mathrm{Itr} / \mathrm{sec} /$ ha in January I. While in August II and September to I with NFR results tertiary plot $=-0.02 \mathrm{ltr} / \mathrm{sec} / \mathrm{ha}$ and DR intake $=-0.03 \mathrm{ltr} / \mathrm{sec} / \mathrm{ha}$ which means surplus water, so that no irrigation is needed from the local irrigation.

3. The mainstay discharge available in the Pauh Tinggi Irrigation Network Planning is very abundant with a mainstay discharge of $80 \%$ (Q80) for irrigation, the maximum mainstay discharge of $80 \%$ (Q80) occurs in November with $160.31 \mathrm{ltr} / \mathrm{sec} / \mathrm{ha}$ and minimum in August with 91.18 liters / sec / ha. This is understandable because the irrigation channel takes intake from the Batanghari river whose watershed is the second largest in Indonesia.

4. Based on the results of the mainstay discharge above it can be stated that the water balance / water balance between the mainstay discharge Q80 and the need for irrigation water has a large surplus. This can be utilized by the Kerinci Regency government to further optimize the benefits of this abundant water supply to the community.

5. In this irrigation rotation, PT tertiary plot of $1 \mathrm{ki}$ is used. This Tertiary plot has a land area of 53.90 ha divided into three sub-tertiary regions, namely sub-tertiary A 7.67 ha and 8.22 ha, subtersier $B 9.65$ ha and 9.10 ha, subtersier $C 9.81$ ha and 9,45 ha. Obtained If $Q$ is available $(65-100) \% Q$ irrigation then the water supply is carried out continuously for 24 hours. If $Q$ is available $(30-65) \% Q$ irrigation, then the method of giving water is divided into 3 periods. If $Q$ is available $<30 \% Q$ irrigation, then the method of giving water is divided into 3 periods in 7 days (168 hours).

\section{Suggestions}

1. Further research needs to be done on the value of optimization of irrigation needs for the economic benefit of the community. 
2. Development of the Kerinci Regency government can be carried out to optimize the benefits of abundant water availability to the community.

\section{REFERENCES}

Agustin, Intan Ratri. 2011. KAJIAN PERENCANAAN KETERSEDIAAN AIR UNTUK POLA TANAM DAERAH IRIGASI KAMAL PADA BENDUNGAN SERMO. Jakarta: s.n., 2011.

Anonym. 2017. PERENCANAAN PETAK TERSIER PT KA 1 KI PADA DAERAH IRIGASI PAUH TINGGI, KABUPATEN KERINCI, JAMBI. Malang : Poluteknik Negeri Malang, 2017.

Anton, Priyonugroho. 2014. Analisis Kebutuhan Air Irigasi (Studi Kasus pada Daerah Irigasi Sungai Air Keban Daerah Kabupaten Empat Lawang), Universitas Sriwijaya. Palembang : s.n., 2014.

Gandakoesoema, R. 1986. Irigasi. Bandung : Galang Persada, 1986.

Kementerian PUPR Ditjen Sumber Daya Air. 2017. Modul Hidrologi dan Ketersediaan air Pusat Pendidikan dan Pelatihan Sumber Daya Air dan Konstruksi. 2017.

KP 01. 2013. Standar Perencanaan Irigasi, Kriteria Perencanaan Bagian Jaringan Irigasi KP-01-09. s.I. : Dep. PU, Dit. Jen. Pengairan, 2013.

KP 03. 2013. Standar Perencanaan Irigasi, Kriteria Perencanaan Bagian Jaringan Irigasi KP-01-09. s.I. : Dep. PU, Dit. Jen. Pengairan, 2013.

KP 05. 2013. Standar Perencanaan Irigasi, Kriteria Perencanaan Bagian Jaringan Irigasi KP-01-09. s.I. : Dep. PU, Dit. Jen. Pengairan, 2013.

Kurniawan, Andrew. 2018. Evaluasi Analisis Hidrologi Perencanaan Bangunan Konsolidasi Dam (KD) 1-1 Sungai Jeneberang, Desa Lonjoboko', Kecamatan Parangloe, Kabupaten Gowa, Sulawesi Selatan. Jakarta : s.n., 2018.

Sidharta, S.K. 1997. Irigasi dan Bangunan Air. Jakarta : Gunadarma, 1997.

Suyono, Sosrodarsono. 2003. Hidrologi Untuk Pengairan. Jakarta: Pradanya Paramta, 2003. 